Volume-V,Issue-02, July-December, 2010

\title{
Socio-Economic Conditions of Female Garment Workers in Chittagong Metropolitan Area-An Empirical Study
}

\author{
NAZNEEN JAHAN CHOWDHUR Y ${ }^{1}$ \\ MD. HAFIJ ULLAH ${ }^{2}$
}

\begin{abstract}
This paper is an endeavor to depict the conditions of the female workers from two perspectives. One is social perspective and the other is economic perspective. The analysis is based on the survey of 151 female workers of 29 garment industrial units located in different parts of Chittagong Metropolitan area. This study suggests that the standard of living of the female garment workers is still in precarious condition and they are not free from the vicious circle of poverty and face extreme difficulties in obtaining their basic needs for survival even. This paper recommends measures for improving the prevailing socio-economic facilities, to a great extent, to achieve female workers' satisfaction at the maximum level.
\end{abstract}

Key Words: Female Garments Workers, Social Factors and Economic Factors.

\section{INTRODUCTION}

The readymade garment industry (RMG) has played a pioneering role in the development of industrial sector of Bangladesh. Though it took a rather late start i.e. in 1976, it soon established its reputation in the world market within a short span of time. Consequently, RMG is now one of the main export items of the country. Besides, enriching the country's economy it has been playing a vital role in alleviating unemployment. In the financial year 1998-99, export-oriented garment sector earned US $\$ 4,020$, which accounted for 75.7 percent of the country's total export earnings. Employment in the RMG sector provides female workers with economic benefits and some empowerment. Over 90 percent of the production workers employed in RMG factories are women. Moreover, the industry accounts

\footnotetext{
${ }^{1}$ Assistant Professor, Department of Business Administration, Faculty of Business Studies, International Islamic University Chittagong.

${ }^{2}$ Assistant Professor, Department of Business Administration, Faculty of Business Studies, International Islamic University Chittagong.
} 
for about 70 percent of the total female employed in the country's manufacturing sector (Bhattacharya and Rahman 2000).

The multimillion dollar garment industry is a major draw for women who migrate to urban areas in Bangladesh in search of work. With the rapid expansion of RMG in the urban areas in the 1980s, there has been a boost in independent migration by young women in Bangladesh. This gives us some perspective to the social mobility with the entry of women in the formal labor market and transition from the private to male dominated public sphere. Recent estimate suggests that 90 percent of the garment industry is comprised of women and more than 90 percent of the garment factory workers are the migrants from rural areas and a bulk of them (three quarters) migrated from landless families (Afsar 2000). The same study indicates that the female workers deserve attention not only because they broke the inherent social norm of being only a daughter, wife or mother of some men, but also because of their emerging role as primary earners. Majumder and Khatun (1997) show that about 30 percent of women are the primary earners of their families, while the others are secondary earners. Without female workers' earnings, 80 percent of their families would slide below the poverty level (Paul-Majumder and Zohir 1995). In spite of discrimination and irregularity in wages and earning below the minimum wages, female workers employed in the export oriented garment industry contribute about 46 percent to their family income. The hands of factory owners are strengthened by the fact that poor unskilled women have few alternatives and even fewer better employment opportunities in any case. Employers prefer female workers not only because they are cheaper and abundantly available, but also because they are more vulnerable, docile and manageable to male workers. They accept without protest the flexible terms of employment and are also seen to be less likely to be organized and susceptible to "anti management propaganda from outside" (Khan 2001). Besides, women workers are more at stake if they lose their jobs since their families depend upon their wages and the alternatives (casual wage work, domestic service) are worse compared with those for men. But some ambiguities and questions about the economic and social conditions of the female garment workers are still existed. In this context, this study was undertaken to assess the socio-economic conditions of the female garment workers in Chittagong Metropolitan Area. To our knowledge, no particular study has been carried out on female garment workers of Chittagong Metropolitan Area--one of the largest garment industrial areas in Bangladesh.

\subsection{Objectives of the Study}

The main objective of the study is to assess the socio-economic conditions of the female garment workers employed in the garment industries located in 
Chittagong Metropolitan area. To achieve the main objective, the study also sets the following specific objectives:

1. To identify the factors that affects the socio-economic conditions of the female garment workers.

2. To assess the social conditions as well as economic position of the female garment workers in our society.

3. To recommend measures to be taken for improving the socio-economic conditions of the female garment workers.

\subsection{Methodology of the Study}

The study has been done on the basis of the following methodology:

a) At the very beginning of the study an intensive literature review has been made. The literature included books, periodicals and journals related to socio-economic conditions of the female garment workers. Female workers were selected as sample because of their high percentage of participation as production workers in RMG factories.

b) The total number of sample for this study was 151 , which were drawn from 29 garment factories situated in different locations of Chittagong Metropolitan area using a convenient sampling technique. Chittagong region was selected as research area because researchers' working place is Chittagong and it was convenient for the researchers to collect data by self financing. Data were collected during November 2009-January 2010. The female workers irrespective of marital and religious status and ranks have been taken into consideration.

c) A self constructed questionnaire was administrated to collect primary data considering the objectives of the study. The questionnaire consists of maximum close-ended and a little bit open ended questions, which was distributed among the female garment workers. The respondents were personally questioned and the questionnaires were filled in by the interviewer based on the response of the respondents.

d) Out of the number of factors that influence socio-economic conditions, the following factors have been selected from each conditions respectively for the study purpose: age and marital status, family members and earning members, level of education, previous jobs and service length, working hours and overtime hours, workers turnover, casual leave, job environment, harassment, application of labor law, facilities of labor union, labor unrest; salary and its payment mode, payment dates, type of bonus, medical 
allowance, maternity leave and related payments, savings, transport facility, satisfaction towards earnings and jobs.

e) Simple statistical techniques like frequency distribution, percentage of frequency were used to analyze the collected data.

\section{ANALYSIS OF THE FINDINGS}

\section{Social Conditions}

1. Age Status of Female RMG Workers in Chittagong Metropolitan Area, 2010

\begin{tabular}{c|c|c|c|c|c}
\hline Age Group & Upto-20 & $21-30$ & $31-40$ & Abv.-41 & Total \\
\hline Frequency & $57(37.75 \%)$ & $64(42.38 \%)$ & $24(15.90 \%)$ & $06(03.97 \%)$ & 151 \\
& & & & $(100 \%)$ \\
\hline
\end{tabular}

Source: Own Survey,November 2009-January 2010.

2. Marital Status of Female RMG Workers in Chittagong Metropolitan Area, 2010

\begin{tabular}{c|c|c|c|c|c|c}
\hline $\begin{array}{c}\text { Marital } \\
\text { Status }\end{array}$ & Unmarried & Married & Divorced & Widow & Others & Total \\
\hline Frequency & $\begin{array}{c}55 \\
(36.42 \%)\end{array}$ & $\begin{array}{c}80 \\
(53.00 \%)\end{array}$ & $\begin{array}{c}10 \\
(06.62 \%)\end{array}$ & $\begin{array}{c}06 \\
(3.96 \%)\end{array}$ & 00 & 151 \\
& & & $(100 \%)$ \\
\hline
\end{tabular}

Source: Own Survey, November 2009-January 2010.

Most of the female workers are belong to young. The study finds that 80.13 percent of the female workers are aged less than 30, while only 3.97 percent of the workers are aged above 41 years. This implies that female workers cannot work in the garment fully for long time because of occupational hazards and workplace stress and the employers do not prefer aged-experienced workers in the factories to reduce cost by employing fresh workers at low remuneration (Majumder \& Begum 2000). Among the female workers surveyed, 53 percent are married and 36.42 percent are unmarried. Majumder and Begum (2000) found that 23 percent of the unmarried garment workers are the main earners of their family.

3. Family Members of Female RMG Workers in Chittagong Metropolitan Area, 2010

\begin{tabular}{c|c|c|c|c|c|c|c}
\hline $\begin{array}{c}\text { Family } \\
\text { Members }\end{array}$ & 1 & 2 & 3 & 4 & 5 & Above 5 & Total \\
\hline Frequency & 03 & 14 & 22 & 28 & 35 & 49 & 151 \\
& $(02.00 \%)$ & $(09.27 \%)$ & $(14.57 \%)$ & $(18.54 \%)$ & $(23.17 \%)$ & $(32.45 \%)$ & $(100 \%)$ \\
\hline
\end{tabular}

Source: Own Survey - November 2009 to January 2010. 
4. Earning Members of Female RMG Workers in Chittagong Metropolitan Area, 2010

\begin{tabular}{c|c|c|c|c|c|c}
\hline $\begin{array}{c}\text { Earning } \\
\text { Members }\end{array}$ & 1 & 2 & 3 & 4 & Above 4 & Total \\
\hline Frequency & $\begin{array}{c}25 \\
(16.56 \%)\end{array}$ & $\begin{array}{c}82 \\
(54.30 \%)\end{array}$ & $\begin{array}{c}34 \\
(22.52 \%)\end{array}$ & $\begin{array}{c}08 \\
(05.30 \%)\end{array}$ & $\begin{array}{c}02 \\
(01.32 \%)\end{array}$ & $\begin{array}{c}151 \\
(100 \%)\end{array}$ \\
\hline
\end{tabular}

Source: Own Survey, November 2009-January 2010.

Cost of living is very much high now. It is also affected by the number of family members, that is, the higher the number of family members, the higher would be the cost of living for the family. Our survey reveals that 55.62 percent of the female workers have 5 or more than 5 family members, while 70.86 percent workers' have one or two earning members. Therefore, it is found that maximum families have 3-4 dependent members whose expenses are borne by only 1-2 earning members. Without female workers' earning, 80 percent of their families would slide below the poverty level (Paul-Majumder and Zohir 1995).

5. Education Level of Female RMG Workers in Chittagong Metropolitan Area, 2010

\begin{tabular}{|c|c|c|c|c|c|c|}
\hline $\begin{array}{c}\text { Level of } \\
\text { Education }\end{array}$ & Illiterate & $\begin{array}{c}\text { Can Sign } \\
\text { Only }\end{array}$ & Class I-V & $\begin{array}{c}\text { Class VI- } \\
\text { X }\end{array}$ & $\begin{array}{c}\text { Above } \\
\text { Class X }\end{array}$ & Total \\
\hline Frequency & $\begin{array}{c}04 \\
(02.65 \%)\end{array}$ & $\begin{array}{c}37 \\
(24.50 \%)\end{array}$ & $\begin{array}{c}58 \\
(38.41 \%)\end{array}$ & $\begin{array}{c}43 \\
(28.48 \%)\end{array}$ & $\begin{array}{c}09 \\
(05.96 \%)\end{array}$ & $\begin{array}{c}151 \\
(100 \%)\end{array}$ \\
\hline
\end{tabular}

Source: Own Survey, November 2009-January 2010.

Education is the backbone and foundation of getting a job and performing better in the job. Increase in the level of workers' education contributes to a reduction in male-female wage differences and to the visible decline in the sexual harassments faced by the female workers in the work place (Mahmud and Ahmed 2005). Our survey indicates that of the total workers served only 2.65 percent are illiterate and 24.5 percent can sign only. On the other hand, 65.56 percent of the workers have education up to class $\mathrm{V}$, while 94.04 percent have education above class X. Because workers educational level is low, their work understanding and working capacity is expected to be poor. For this, they get poor remuneration and facilities from employers. 
6. Nature of Job Experience of Female RMG Workers in Chittagong Metropolitan Area, 2010

\begin{tabular}{c|c|c|c|c|c|c}
\hline $\begin{array}{c}\text { Nature of job } \\
\text { Experience }\end{array}$ & Unemployed & $\begin{array}{c}\text { Agro- } \\
\text { based } \\
\text { Job }\end{array}$ & Handicraft & Garments & Other & Total \\
\hline Frequen & $61(40.40 \%)$ & $\begin{array}{c}01 \\
(00.65 \%)\end{array}$ & $(02.65 \%)$ & $(51.66 \%)$ & $(04.64 \%)$ & $(100 \%)$ \\
\hline
\end{tabular}

Source: Own Survey, November 2009-January 2010.

7. Duration of Job Experience of Female RMG Workers in Chittagong Metropolitan Area, 2010

\begin{tabular}{l|c|c|c|c|c|c}
\hline $\begin{array}{c}\text { Job } \\
\text { Experience }\end{array}$ & $\begin{array}{c}\text { Less than } \\
2 \text { years }\end{array}$ & $2-3$ Years & $3-5$ years & $5-7$ years & $\begin{array}{c}\text { Above } 7 \\
\text { years }\end{array}$ & Total \\
\hline Frequency & $\begin{array}{c}57 \\
(37.75 \%)\end{array}$ & $\begin{array}{c}33.85 \%) \\
(12.58 \%)\end{array}$ & $(09.27 \%)$ & $(18.55 \%)$ & $(100 \%)$ \\
\hline
\end{tabular}

Source: Own Survey, November 2009-January 2010.

Experience is an extra advantageous factor for getting a job and getting higher amount of remuneration in any organization. The survey finds that more than 40 percent of the workers were unemployed or have no previous work experience in garment industries. Therefore, in most cases they are not capable of providing expected performance to the employer and hence being deprived appropriate remuneration. About 52 percent of the female workers have work experience in garment factories and about 60 percent have only 3 years experience. Job opportunities for women in Bangladesh are limited because of cultural barriers and limited mobility. They also lack access to education, skill development opportunities, and productive resources; moreover, they bear the burden of household responsibilities. As women contribute significantly to the garment industry for more export of garment industry, some manufacturers are now paying value women at work.

8. Working hours of Female RMG Workers in Chittagong Metropolitan Area, 2010

\begin{tabular}{l|c|c|c|c|c|c}
\hline Work Hours & $\begin{array}{c}\text { Less than } \\
8 \text { hours }\end{array}$ & $\begin{array}{c}8-9 \\
\text { hours }\end{array}$ & $\begin{array}{c}9-10 \\
\text { hours }\end{array}$ & $\begin{array}{c}11-12 \\
\text { hours }\end{array}$ & $\begin{array}{c}\text { Above } \\
12 \text { hours }\end{array}$ & Total \\
\hline Frequency & $\begin{array}{c}07 \\
(04.64 \%)\end{array}$ & $\begin{array}{c}93 \\
(61.59 \%)\end{array}$ & $\begin{array}{c}37 \\
(24.50 \%)\end{array}$ & $\begin{array}{c}07 \\
(04.64 \%)\end{array}$ & $\begin{array}{c}07 \\
(04.64 \%)\end{array}$ & $\begin{array}{c}151 \\
(100 \%)\end{array}$ \\
\hline
\end{tabular}

Source: Own Survey, November 2009-January 2010. 
9. Overtime work hours of Female RMG Workers in Chittagong Metropolitan Area, 2010

\begin{tabular}{c|c|c|c|c|c|c}
\hline $\begin{array}{c}\text { Overtime Work } \\
\text { Hours }\end{array}$ & $0-30$ & $31-60$ & $61-90$ & $91-120$ & $\begin{array}{c}\text { Above } \\
120\end{array}$ & Total \\
\hline Frequency & 34 & 58 & 35 & 21 & 03 & 151 \\
& $(22.52 \%)$ & $(38.41 \%)$ & $(23.18 \%)$ & $(13.91 \%)$ & $(02.00 \%)$ & $(100 \%)$ \\
\hline
\end{tabular}

Source: Own Survey, November 2009-January 2010.

The most tedious condition of work in the garment factories is the long working hours. According to section 100 of the the Bangladesh Labour Act (BLA) of 2006, no adult worker shall ordinarily be required or allowed to work in an establishment for more than 8 hours a day. Of the total women workers surveyed, 33.78 percent work more than 9 hours a day, while 95.36 percent work more than 8 hours a day. Overtime work is an advantage and an extra earning source for the female garment workers. According to Section 109 of the BLA, 2006, no women shall, without her consent, be allowed to work in an establishment between the hours of 10.00 p.m. and 6.00 a.m. About 40 percent of the workers work more than 2 of hours overtime a day, while15.91 percent work more than 3 hours of overtime a day. In some cases, workers do overtime in the week end. As their salary is very low, they always try to earn some extra amount from overtime. Hence, they cannot provide much time for their family or children. As a result, they become unhappy in their family life. Moreover, female workers are obliged to shorten their time for pleasure and sleep due to long working hours and all domestic chores (Majumder \& Begum 2000).

10. Duration (in days) of Casual Leave of Female RMG Workers in Chittagong Metropolitan Area, 2010

\begin{tabular}{c|c|c|c|c|c|c}
\hline Days & No Leave & $0-5$ & $6-10$ & $10-15$ & $16-20$ & Total \\
\hline Frequency & 12 & 19 & 46 & 53 & 21 & 151 \\
& $(07.95 \%)$ & $(12.58 \%)$ & $(30.47 \%)$ & $(35.10 \%)$ & $(13.90 \%)$ & $(100 \%)$ \\
\hline
\end{tabular}

Source: Own Survey, November 2009-January 2010.

According to BLA of 2006, every worker shall be entitled to enjoy casual leave with full wages for ten days in a calendar year. Our study reveals that about 8 percent of the workers do not enjoy any casual leave with pay and more than 50 percent of the workers get less than 10 days of casual leave per year. In some cases the workers are bound to work even they are sick. The absence of leave facilities is another factor that makes the terms and conditions of garment employment very stringent. 
11. Accommodation Expenses (Tk.) of Female RMG Workers in Chittagong Metropolitan Area, 2010

\begin{tabular}{c|c|c|c|c|c|c}
\hline $\begin{array}{c}\text { Amount of } \\
\text { money (Tk.) }\end{array}$ & $0-500$ & $501-1000$ & $\begin{array}{c}1001- \\
1500\end{array}$ & $\begin{array}{c}1501- \\
2000\end{array}$ & $\begin{array}{c}\text { Above } \\
2000\end{array}$ & Total \\
\hline Frequency & $\begin{array}{c}30 \\
(19.87 \%)\end{array}$ & $\begin{array}{c}51 \\
(33.77 \%)\end{array}$ & $\begin{array}{c}42 \\
(27.81 \%)\end{array}$ & $\begin{array}{c}12 \\
(07.95 \%)\end{array}$ & $\begin{array}{c}16 \\
(10.60 \%)\end{array}$ & $\begin{array}{c}151 \\
(100 \%)\end{array}$ \\
\hline
\end{tabular}

Source: Own Survey, November 2009-January 2010.

A problem faced by working women (migrants), particularly in urban areas, is the lack of proper accommodation. Khan (1993) notes that it is terribly expensive for a single woman to rent an accommodation on her own. It is also difficult to find a landlord who would let out his place to a single woman. The study finds that 73.40 percent female workers live in a house with family and only 1.5 percent lives alone. During the field work it is observed that women face extreme hardships to make ends meet because of low wages and higher rental costs. Rent usually consumes 60 percent of the monthly wage of a worker. Zohir and Paul-Majumder (1996), PaulMajumder and Begum (2000) and Zohir (2000) have done extensive research on the housing of garment workers. Their studies show that accommodation in the city is not adequate for workers.

12. 'Workers Turnover of Female RMG Workers in Chittagong Metropolitan Area, 2010

\begin{tabular}{c|c|c|c|c|c|c|c|c}
\hline $\begin{array}{c}\text { No. of } \\
\text { Factories } \\
\text { changed }\end{array}$ & 0 & 1 & 2 & 3 & 4 & 5 & $\begin{array}{c}\text { More } \\
\text { Than 5 }\end{array}$ & Total \\
\hline Frequency & $\begin{array}{c}75 \\
(49.67 \%)\end{array}$ & $\begin{array}{c}35 \\
(23.18 \%)\end{array}$ & $\begin{array}{c}27 \\
(17.88 \%)\end{array}$ & $\begin{array}{c}07 \\
(04.63 \%)\end{array}$ & $\begin{array}{c}04 \\
(02.64 \%)\end{array}$ & $\begin{array}{c}00 \%) \\
(00 \%)\end{array}$ & $\begin{array}{c}03 \\
(02.00 \%)\end{array}$ & \begin{tabular}{c}
$(100 \%)$ \\
\hline
\end{tabular}
\end{tabular}

Source: Own Survey, November 2009-January 2010.

A worker cannot find any legal aid to establish his or her claim since he or she is not given any appointment letter against his her job. Appointment is given only on the basis of verbal contract. Though this strategy is useful in checking high turnover rate, our study reveals that rate of turnover among the female garment workers is low i.e. about 50 percent of the workers have not changed their jobs at all. Skilled and experienced workers changed their jobs frequently. About 27 percent of the workers worked in more than two garment factories. 
13. Job Environment of Female RMG Workers in Chittagong Metropolitan Area, 2010

\begin{tabular}{c|c|c|c|c|c|c}
\hline Level & Very Bad & Bad & Neutral & Good & $\begin{array}{c}\text { Very } \\
\text { Good }\end{array}$ & Total \\
\hline Frequency & $\begin{array}{c}04 \\
(02.65 \%)\end{array}$ & $\begin{array}{c}17 \\
(11.26 \%)\end{array}$ & $\begin{array}{c}32 \\
(21.19 \%)\end{array}$ & $\begin{array}{c}72 \\
(47.68 \%)\end{array}$ & $\begin{array}{c}26 \\
(17.22 \%)\end{array}$ & $\begin{array}{c}151 \\
(100 \%)\end{array}$ \\
\hline
\end{tabular}

Source: Own Survey, November 2009-January 2010.

Job environment is a vital factor for the garment workers, specifically for female garment workers. Our survey finds that job or work environment is quite good in the surveyed garment factories. Only about 14 percent of the female workers are dissatisfied with their job environment, while 65 percent are happy with their job environment and remaining 21 percent are neutral in this regard. The better job environment was possible to achieve due to imposition of terms and conditions by foreign buyers and strict monitoring of the government regulatory authorities.

14. Nature of Harassment/Torture of Female RMG Workers in Chittagong Metropolitan Area, 2010

\begin{tabular}{c|c|c|c|c|c|c}
\hline Structure & $\begin{array}{c}\text { No } \\
\text { Harassment }\end{array}$ & Physical & Mental & Sexual & Others & Total \\
\hline Frequency & $\begin{array}{c}75 \\
(49.67 \%)\end{array}$ & $(08.61 \%)$ & $(25.17 \%)$ & $(08.61 \%)$ & $(07.94 \%)$ & $(100 \%)$ \\
\hline
\end{tabular}

Source: Own Survey, November 2009-January 2010.

Harassment by male colleagues or by management in the workplace is very common for the female workers in the garment industries. As per our survey result, more than 50 percent of the female workers are harassed/tortured physically, mentally, sexually or other ways. On the other hand, 49.67 percent of the female workers opined that there is no harassment at their workplace. Increased level of education and awareness about labor rights keep harassment of the female workers at the minimum level (Mahmud 2009).

15. Application o Labor law of Female RMG Workers in Chittagong Metropolitan Area, 2010

\begin{tabular}{c|c|c|c|c|c|c}
\hline Class & $\begin{array}{c}\text { Don't } \\
\text { Know }\end{array}$ & $\begin{array}{c}\text { No } \\
\text { Application }\end{array}$ & $\begin{array}{c}\text { Few } \\
\text { Application }\end{array}$ & $\begin{array}{c}\text { Good } \\
\text { Application }\end{array}$ & Others & Total \\
\hline Frequency & 77 & 10 & 29 & 34 & 01 & 151 \\
& $(51.00 \%)$ & $(06.62 \%)$ & $(19.20 \%)$ & $(22.52 \%)$ & $00.66 \%)$ & $(100 \%)$ \\
\hline
\end{tabular}

Source: Own Survey, November 2009-January 2010. 
The Bangladesh Labour Act, 2006, Factories Act of 1965 and the Factories Rules of 1979 all provide protection to labor force. Of the surveyed female workers, 51 percent reported that they do not know about the application of labor laws in their garments, while 25.82 percent of the workers reported that there is no or little application of the laws in their garment industries. Since existing labour legislation assumes a predominantly male workforce, it is often at a loss to deal with the specific needs and concerns of an overwhelmingly female and unskilled workforce employed in garment manufacturing industries (Mahmud 2009).

16. Facilities of Labor Union of Female RMG Workers in Chittagong Metropolitan Area, 2010

\begin{tabular}{l|c|c|c|c|c}
\hline Class & No Union & $\begin{array}{c}\text { Prohibited } \\
\text { by Owners }\end{array}$ & $\begin{array}{c}\text { Manage Top } \\
\text { Leaders }\end{array}$ & Others & Total \\
\hline Frequency & $\begin{array}{c}85 \\
(56.30 \%)\end{array}$ & $\begin{array}{c}09 \\
(05.96 \%)\end{array}$ & $\begin{array}{c}55 \\
(36.42 \%)\end{array}$ & $\begin{array}{c}02 \\
(01.32 \%)\end{array}$ & $\begin{array}{c}151 \\
(100 \%)\end{array}$ \\
\hline
\end{tabular}

Source: Own Survey, November 2009-January 2010.

According to section 176 of the Bangladesh Labor Act 2006, workers, without distinction whatsoever, shall have the right to form trade union primarily for the purpose of regulating the relations between workers and employers or workers and workers and, subject to the constitution of the union concerned, to join trade union of their own choosing. The survey reveals that 56 percent of the female workers said that labor union did not exist in their factories because the owners and management were extremely averse to any types of unionization of their workforce; 36.42 percent of the workers reported that though trade union existed in their industries, the leaders of the union are managed by the authority; they do not work for the workers but only serve the interest of the owners of the garment factory. There are about 14 federations of factory workers unions in the country, but many of them are in name only and are not registered with the Directorate of Labour (Khan 2001). But it is also true that the garment workers are still, by and large, reluctant to join trade and labor unions (Mahmud 2009).

17. Causes of Labor Unrest in Chittagong Metropolitan Area, 2010

\begin{tabular}{c|c|c|c|c|c|c}
\hline Class & $\begin{array}{c}\text { Don't } \\
\text { Know }\end{array}$ & $\begin{array}{c}\text { Reduce } \\
\text { Exploitation }\end{array}$ & $\begin{array}{c}\text { Influence } \\
\text { by Leader }\end{array}$ & $\begin{array}{c}\text { Increase } \\
\text { Salaries }\end{array}$ & Others & Total \\
\hline Frequency & 57 & 12 & 15 & 51 & 16 & 151 \\
& $(37.75 \%)$ & $(07.95 \%)$ & $(09.93 \%)$ & $(33.77 \%)$ & $(01.10 \%)$ & $(100 \%)$ \\
\hline
\end{tabular}

Source: Own Survey, November 2009-January 2010. 
Nowadays labor unrest is a serious problem for the garment industries and for the country as well. One party (segments of the labors) blames another party for the creation of unrest in the garment industries and in most of the cases the blames go towards the workers of the garment. About 38 percent of the female workers said that they have no knowledge about the causes of unrest, while $52 \%$ report that the reasons are reduce the exploitation and harassments, influence of the leaders and demand of increase salaries. Therefore, according to their opinion, among the reasons of unrest, salary and salary related matters induce the workers more. Hence, it can be said that if the workers are paid just and appropriate salaries and perquisites in time, then the unrest in the garment industries would be eliminated or reduced to a great extent.

\section{Economic Conditions}

1. Periodical Salary Structure of Female RMG Workers in Chittagong Metropolitan Area, 2010

\begin{tabular}{c|c|c|c|c|c|c}
\hline $\begin{array}{c}\text { Salary } \\
\text { structure }\end{array}$ & Weekly & Monthly & $\begin{array}{c}\text { Hours } \\
\text { worked }\end{array}$ & $\begin{array}{c}\text { Units of } \\
\text { work }\end{array}$ & Others & Total \\
\hline Frequency & 00 & $\begin{array}{c}148 \\
(98.00 \%)\end{array}$ & $03(02.00 \%)$ & 00 & 00 & 151 \\
& & & & $(100 \%)$ \\
\hline
\end{tabular}

Source: Own Survey, November 2009-January 2010.

2. Basic Salary (Tk.) Structure per month of Female RMG Workers in Chittagong Metropolitan Area, 2010

\begin{tabular}{l|c|c|c|c|c|c}
\hline $\begin{array}{c}\text { Amount of } \\
\text { salary (Tk.) }\end{array}$ & Below 500 & $500-1000$ & $1001-1500$ & $1501-2000$ & $\begin{array}{c}\text { Above } \\
2000\end{array}$ & Total \\
\hline Frequency & 01 & & & & \\
& $(00.66 \%)$ & $(03.97 \%)$ & $(19.87 \%)$ & $(31.13 \%)$ & $(44.37 \%)$ & $(100 \%)$ \\
\hline
\end{tabular}

Source: Own Survey, November 2009-January 2010.

3. Total Salary Structure per month of Female RMG Workers in Chittagong Metropolitan Area, 2010

\begin{tabular}{c|c|c|c|c|c|c}
\hline $\begin{array}{c}\text { Amount of } \\
\text { salary } \\
\text { (Tk.) }\end{array}$ & $\begin{array}{c}1000- \\
2000\end{array}$ & $2001-3000$ & $\begin{array}{c}3001- \\
4000\end{array}$ & $\begin{array}{c}4001- \\
5000\end{array}$ & $\begin{array}{c}\text { Above } \\
5000\end{array}$ & Total \\
\hline Frequency & 08 & 37 & 63 & 16 & 27 & 151 \\
& $(05.30 \%)$ & $(24.50 \% 0$ & $(41.72 \%)$ & $(10.60 \%)$ & $(17.88 \%)$ & $(100 \%)$ \\
\hline
\end{tabular}

Source: Own Survey, November 2009-January 2010. 
Salaries and perquisites are the main factors that determine the economic position and life standard of garment workers. Our survey reveals that 71.52 percent of the female workers get Tk. 4,000 or less as total pay per month, which is really insufficient to lead their life with 3-4 dependent members in the family. Only 18 percent of the female workers get more than Tk. 5,000 as total monthly salary. Women labors are very cheap in Bangladesh but they are employed in this industry to exploit the comparatives advantages of their disadvantages like the low price of their labor, their low bargaining power, and their docility (Majumder \& Begum 2000). Women are getting low salaries as they are employed in lower level and unskilled jobs. A study indicates that the female workers earn only about 60 percent of the earnings of the male workers (Majumder \& Begum, 2000).

4. Modes of Salary payment of Female RMG Workers in Chittagong Metropolitan Area, 2010

\begin{tabular}{c|c|c|c|c|c}
\hline $\begin{array}{c}\text { Payment } \\
\text { Dates }\end{array}$ & $25^{\text {th }}$-last day & $1^{\text {st }}-10^{\text {th }}$ day & $10^{\text {th }}-15^{\text {th }}$ day & $\begin{array}{c}\text { After } 15^{\text {th }} \\
\text { day }\end{array}$ & Total \\
\hline Frequency & $05(03.31 \%)$ & $37(24.50 \%)$ & $73(48.35 \%)$ & $36(23.84 \%)$ & $151(100 \%)$ \\
\hline
\end{tabular}

Source: Own Survey, November 2009-January 2010.

The workers are not only deprived of appropriate amount of salary but also deprived of getting the salary in time. According to the section 123 of the BLA, 2006 , the wages of every worker shall be paid within seven days after the expiry of the wage period. Our survey result shows that only 24.50 percent of the workers get their salary of the last month before $10^{\text {th }}$ day of the next month, 48.35 percent get their salaries of the last month before $15^{\text {th }}$ day of the next month and 23.84 percent of the workers need to wait more than 15 days to get their salaries of the last month.

5. Bonus Structure of Female RMG Workers in Chittagong Metropolitan Area, 2010

\begin{tabular}{l|c|c|c|c|c|c}
\hline $\begin{array}{l}\text { Bonus } \\
\text { structure }\end{array}$ & $\begin{array}{c}\text { On time } \\
\text { attendance }\end{array}$ & $\begin{array}{c}\text { Regular } \\
\text { Attendance }\end{array}$ & Festival & $\begin{array}{c}\text { Production } \\
\text { Efficiency }\end{array}$ & Others & Total \\
\hline Frequency & 00 & $\begin{array}{c}07 \\
(04.64 \%)\end{array}$ & $\begin{array}{c}127 \\
(84.10 \%)\end{array}$ & $\begin{array}{c}10 \\
(06.62 \%)\end{array}$ & $\begin{array}{c}07 \\
(04.64 \%)\end{array}$ & \begin{tabular}{c}
$100 \%)$ \\
\hline
\end{tabular} \\
\hline
\end{tabular}

Source: Own Survey, November 2009-January 2010. 
Basically, different types of bonuses are given to the workers for encouraging them for better performance and sincerity in the work. But more than 84 percent of the female garment workers get only festival bonus from their employers, 6.62 percent get bonus for production efficiency and 4.64 percent of the workers get bonus for regular attendance in the work. The authority of the garment industries may distribute a part of their profit to the workers to give them a sense of ownership and make them more responsible in the work.

6. Medical Allowance System of Female RMG Workers in Chittagong Metropolitan Area, 2010

\begin{tabular}{c|c|c|c|c|c}
\hline $\begin{array}{c}\text { Medical } \\
\text { Allowances }\end{array}$ & $\begin{array}{c}\text { No } \\
\text { payment }\end{array}$ & $\begin{array}{c}\text { Paid as per } \\
\text { Medical } \\
\text { Documents }\end{array}$ & $\begin{array}{c}\text { One time } \\
\text { payment }\end{array}$ & Others & Total \\
\hline Frequency & $\begin{array}{c}40 \\
(26.49 \%)\end{array}$ & $\begin{array}{c}106 \\
(70.20 \%)\end{array}$ & $\begin{array}{c}04 \\
(02.65 \%)\end{array}$ & $\begin{array}{c}01 \\
(00.66 \%)\end{array}$ & $\begin{array}{c}151 \\
(100 \%)\end{array}$ \\
\hline
\end{tabular}

Source: Own Survey, November 2009-January 2010.

One of the basic needs of the human being is medical allowances from the employer but it is very unfortunate that 26.49 percent of the surveyed female workers get nothing from their employers for medications if they make any accident or become sick. According to the BLA 2006, in every establishment wherein three hundred or more workers are ordinarily employed, there shall be provided and maintained a sick room with dispensary of the prescribed size, containing the prescribed equipment or similar facilities, in the charge of such medical nursing staff as may be prescribed.

7. Duration of Maternity leave of Female RMG Workers in Chittagong Metropolitan Area, 2010

\begin{tabular}{c|c|c|c|c|c|c|c}
\hline $\begin{array}{c}\text { Leave } \\
\text { structure }\end{array}$ & No leave & $\begin{array}{c}1- \\
\text { Month }\end{array}$ & $\begin{array}{c}2- \\
\text { Months }\end{array}$ & $\begin{array}{c}3- \\
\text { Months }\end{array}$ & $\begin{array}{c}4- \\
\text { Months }\end{array}$ & $\begin{array}{c}\text { More } \\
\text { than 4 } \\
\text { Months }\end{array}$ & Total \\
\hline Frequency & $\begin{array}{c}10 \\
(06.62 \%)\end{array}$ & $\begin{array}{c}02 \\
(01.32 \%)\end{array}$ & $\begin{array}{c}07 \\
(04.64 \%)\end{array}$ & $\begin{array}{c}50 \\
(33.12 \%)\end{array}$ & $\begin{array}{c}82 \\
(54.30 \%)\end{array}$ & 00 & 151 \\
&
\end{tabular}

Source: Own Survey, November 2009-January 2010. 
8. Payment Structure of Maternity leave of Female RMG Workers in Chittagong Metropolitan Area, 2010

\begin{tabular}{l|c|c|c|c|c}
\hline $\begin{array}{l}\text { Payment } \\
\text { Structure }\end{array}$ & $\begin{array}{c}\text { No } \\
\text { Payment }\end{array}$ & $\begin{array}{c}\text { Regular } \\
\text { Salary }\end{array}$ & $\begin{array}{c}\text { Paid as per medical } \\
\text { document }\end{array}$ & Others & Total \\
\hline Frequency & 20 & 103 & $28(18.54 \%)$ & 00 & 151 \\
& $(13.25 \%)$ & $(68.21 \%)$ & & $(100 \%)$ \\
\hline
\end{tabular}

Source: Own Survey, November 2009-January 2010.

Maternity leave is a basic and humanitarian right of the female garment workers but all the garments factories are not giving maternity leave to their workers with pay. According to Maternity Benefit Act 1950, the maternity leave was of 12 weeks. The new BLA 2006 increases the maternity leaves to 16 weeks from 12 weeks and the maternity benefit which is payable under section 48 of this act shall be payable at the rate of daily, weekly or monthly average wages and such payment shall be made wholly in cash. Our survey revealed that 7 percent of the workers are granted 8 weeks or less maternity leave, 33.12 percent get 12 weeks, 54.30 percent granted 16 weeks and only 6.62 percent granted no leave. While 3.25 percent of the female workers are paid nothing during their maternity leave, remaining 86.75 percent of the workers get either regular salaries or an amount based on the medical documents.

9. Amount of Savings (Tk.) per Month of Female RMG Workers in Chittagong Metropolitan Area, 2010

\begin{tabular}{c|c|c|c|c|c|c}
\hline $\begin{array}{c}\text { Savings } \\
\text { per month } \\
\text { (Tk.) }\end{array}$ & $0-500$ & $501-1000$ & $\begin{array}{c}1001- \\
1500\end{array}$ & $\begin{array}{c}1501- \\
2000\end{array}$ & $\begin{array}{c}\text { Above } \\
2000\end{array}$ & Total \\
\hline Frequency & $\begin{array}{c}101 \\
(66.89 \%)\end{array}$ & $\begin{array}{c}37 \\
(24.50 \%)\end{array}$ & $\begin{array}{c}09 \\
(05.96 \%)\end{array}$ & $\begin{array}{c}01 \\
(00.65 \%)\end{array}$ & $\begin{array}{c}03 \\
(02.00 \%)\end{array}$ & \begin{tabular}{c}
$(100 \%)$ \\
\hline
\end{tabular} \\
\hline
\end{tabular}

Source: Own Survey, November 2009-January 2010.

Saving is an important factor that affects the socio-economic condition of the garment workers. The survey result indicates that about 67 percent of the workers can save Tk. 500 or less per month and more than 90 percent of the workers can save Tk. 1,000 or less per month. Earlier there was no income and savings of these female workers. The tendency of savings has increased over the years (Majumder 1998). 
10. Transport Facility of Female RMG Workers in Chittagong Metropolitan Area, 2010

\begin{tabular}{ccccccc}
\hline $\begin{array}{c}\text { Facility } \\
\text { Structure }\end{array}$ & $\begin{array}{c}\text { No } \\
\text { facility }\end{array}$ & One way & Both way & $\begin{array}{c}\text { Transport } \\
\text { allowance }\end{array}$ & Others & Total \\
\hline Frequency & $\begin{array}{c}67 \\
(44.37 \%)\end{array}$ & $\begin{array}{c}10 \\
(06.62 \%)\end{array}$ & $\begin{array}{c}57 \\
(37.75 \%)\end{array}$ & $\begin{array}{c}12 \\
(07.95 \%)\end{array}$ & $\begin{array}{c}05 \\
(03.31 \%)\end{array}$ & $\begin{array}{c}151 \\
(100 \%)\end{array}$ \\
\hline
\end{tabular}

Source: Own Survey, November 2009-January 2010.

Workers come to the industries from different locations due to non-availability of the dwelling houses near to their factories. Zohir and Paul-Majumder (1996) show that living in a factory accommodation is the most secure housing system. Our study reveals that 44.37 percent of the female workers not avail any transport facility, while 37.75 percent are provided with two way transport facility; only 6.62 are provided with transport facility. Majumder and Khatun (1997) found that 70 percent of the female garments workers traveled by bus experienced bad behavior by conductors and drivers; hence, the workers are willing to pay more for safe and secure transport facilities.

11. Satisfaction towards Earnings of Female RMG Workers in Chittagong Metropolitan Area, 2010

\begin{tabular}{c|c|c|c|c|c|c}
\hline $\begin{array}{c}\text { Level of } \\
\text { Satisfaction }\end{array}$ & Very bad & Bad & Neutral & Good & $\begin{array}{c}\text { Very } \\
\text { good }\end{array}$ & Total \\
\hline Frequency & $\begin{array}{c}07 \\
(04.64 \%)\end{array}$ & $\begin{array}{c}20 \\
(13.25 \%)\end{array}$ & $\begin{array}{c}36 \\
(23.84 \%)\end{array}$ & $\begin{array}{c}67 \\
(44.37 \%)\end{array}$ & $\begin{array}{c}21 \\
(13.90 \%)\end{array}$ & $\begin{array}{c}151 \\
(100 \%)\end{array}$ \\
\hline
\end{tabular}

Source: Own Survey, November 2009-January 2010.

12. Satisfaction towards job of Female RMG Workers in Chittagong Metropolitan Area, 2010

\begin{tabular}{c|c|c|c|c|c|c}
\hline $\begin{array}{c}\text { Level of } \\
\text { Satisfaction }\end{array}$ & Very Bad & Bad & Neutral & Good & $\begin{array}{c}\text { Very } \\
\text { good }\end{array}$ & Total \\
\hline Frequency & 10 & 16 & 46 & 59 & 20 & 151 \\
& $(06.62 \%)$ & $(10.59 \%)$ & $(30.46 \%)$ & $(39.07 \%)$ & $(13.25 \%)$ & $(100 \%)$ \\
\hline
\end{tabular}

Source: Own Survey, November 2009-January 2010.

Degree of satisfaction of a worker is a subjective judgment. So the level of satisfaction has been measured by scaling into five categories such as very bad, bad, neutral, good and very good. It is observed that the satisfaction level of the female garment workers towards earnings and overall jobs is in, rated average, as good. But 
it does not mean that they are earning more because 82.12 percent of the female workers get Tk. 5,000 or less per month in total. As per the survey, 58.27 percent of the female workers are satisfied with their earnings and 17.89 percent are dissatisfied. More satisfaction of the female workers may be derived from their realization that they could be unemployed and what they are getting is good for them, or from their awareness of their education, job experience, and socioeconomic conditions of the country. It is motivating factor for the survival and stability of garment workers in Bangladesh.

\section{RECOMMENDATIONS AND CONCLUSION}

\subsection{Recommendations}

The study recommends the following to protect the interest of the female workers and to save them from harassment:

a) In maximum cases, the amount of salaries paid to the female workers and the date of payment of salaries negatively affects the life standard of the female workers and creates dissatisfaction among the workers. Therefore, the Government, BGMEA and owners of the garment industries should take initiative to provide reasonable and standard amount of salaries as per their position and services just at the end of the month or within the $5^{\text {th }}$ day of the next month.

b) Long working hours due to working at more regular and overtime hours create many problems for the female workers at their families. If salaries and remuneration are increased up to a level of standard, then the intention of doing more overtime can be reduced and thus the length of working hours can be minimized; as a result, more employment facilities will be created in the garment industries for female workers.

c) Job environment is to be made more hygienic and safe for the female workers and compliance report may be sought for sustainable development of the industries. The owners or the management may arrange day care center, school, etc. for the children of the female workers at the factory premises.

d) Accommodation and transportation facilities are very acute for the female workers of the garment industries. Therefore, housing and transportation facilities (both way) are to be arranged by the garment industries.

e) Educational level of the female garment workers is very low; they work at lower positions due to this their productivity is poor. Hence, they get poor salaries and they cannot claim for more. If the educational level of the workers can be developed then their productivity will increase and they will 
be able to perform better and earn more. For educational development, the garment owners should establish educational institutes and training centers to make them educated about different rules and regulations as well as make them aware of their responsibilities.

f) Due to long working hours at the unhygienic job environment, the female workers fall sick frequently. They get no or very poor support from their industries in this regard. Garment industries should set up medical center or at least appoint minimum number of medical officers or female doctors, especially for the female workers.

g) Torture and different types of harassment are very common in the garment industries; in some cases these tortures cause deaths of the workers during office time. Female officers may be appointed or the male officers may be given sufficient training to reduce torture and harassment towards female workers.

h) Activation or introduction of labor union as bargaining authority in real sense is to be ensured in each garment industry to communicate the claims of the workers to the higher authority and the message from the higher authority to the workers. Female representative is to be ensured in the leadership of the union.

i) Though Bangladesh has enacted Labor Law (Act) to ensure the rights and obligations of the female workers in the garment industries but the provisions of the labor law are far from implementation. Basically, the management of the garment industries is frequently violating the law. Therefore, government and BGMEA should be aware of the violation of the law against the poor female garment workers.

\subsection{Conclusion}

The garment sector in Bangladesh contributes more than 70 percent of the national income and 80 percent of the garment workers are female. Due to participation in this income generating sector their life and status in the society got upgraded. However, largely, the condition of female garment workers is very frustrating. Women workers face various crises in the RMG sector. The print media had written many reports and the TV channels had aired many pathetic stories on their low wages, unfriendly working environment, health issues, nutrition, insurance, etc. but feeble measures have been taken so far to address these problems. Overall, these problems are hampering the production and environment of the RMG sector and if these obstacles are not removed, the sector may be affected more and more in the coming days. Last but not the least, the poor female 
garment workers, who are the major workforce behind this sector, must be recognized properly and concrete ideas and their implementation should come to lessen the plight of them. Unless and until the basic rights of the poor female garment workers are ensured, it may not be expected that this sector will achieve its desired goal. If the recommended measures are implemented in the RMG sector then it may improve the present situation and the workers and owners may achieve their goal.

\section{References}

Afsar, Rita. 2000. "Female Labour Migration and Urban Adaptation." A paper presented at the national seminar on Growth of Garment Industry in Bangladesh: Economic and Social Dimensions, 21-22 January, 2000 organized by BIDS in collaboration with OXFAM-GB, Bangladesh.

Bangladesh Employers' Federation. 2009. A Handbook on the Bangladesh Labour Act, 2006.

Bhattacharya, D. and M. Rahman. 2000. Bangladesh's Apparel Sector: Growth Trends and the Post-MFA Challenges. Proceedings of a national seminar on Growth of Garment Industry in Bangladesh: Economic and Social Dimensions, BIDS and OXFAM-GB Bangladesh, Dhaka.

Khan, S.I. 2001. "Gender Issues and the Readymade Garment Industry of Bangladesh: The Trade Union Context." In R Sobhan and N Khundker (eds.) Globalization and Gender: Changing Patterns of Women's Employment in Bangladesh. Dhaka: University Press Ltd.

Mahmud, S. 2009. "Why do Garment Workers in Bangladesh Fail to Mobilize?" Bangladesh Institute of Development Studies, January 28.

Majumder, P.P. and A. Begum. 2000. "The Gender Imbalances in the Export Oriented Garment Industry in Bangladesh.” Working paper Series No. 12, Bangladesh Institute of Development Studies, June.

Majumder, P.P. and M.S Khatun. 1997. "Gender Dimension of Transportation in Dhaka Metropolitan Area." A study prepared for Dhaka Urban Transport Project, World Bank/ Nari Uddog Kendra/ Government of Bangladesh, Mimeo, Dhaka, Bangladesh.

Majumder, P.P. and S.C. Zohir. 1995. "Empowering Women: Wage Employment in the Garments Industry." Journal of Women for Women, November 2.

Mahmud, S. and N. Ahmed. 2005. "Accountability for Workers Rrights' in the Export Garment Sector in Bangladesh.” Draft, Bangladesh Institute of Development Studies (BIDS), Dhaka.

Sarker, M.M.R. 1997. Status of the Workers in the Garment Industries, Dhaka University Journal of Business Studies, 18 (1):153-169. 